\title{
Importance of 1,4-dimethylnaphthalene in maintaining the quality of stored tubers of Asterix and Challenger cultivars
}

\author{
Abelardo Barreto de MENDONÇA NETO ${ }^{1}$, Maria Eduarda da Silva GUIMARÃES ${ }^{1 \star}$ (D), Ariana Mota PEREIRA, \\ Renata Ranielly Pedroza CRUZ1 ${ }^{1}$, Dreice Nascimento GONÇALVES ${ }^{1}$, Luciana Gomes SOARES ${ }^{1}$, \\ Ana Izabella FREIRE ${ }^{1}$, Fernando Luiz FINGER ${ }^{1}$, Paulo Roberto CECON ${ }^{2}$
}

\begin{abstract}
This work aimed to analyze 1,4-DMN efficiency in the suppression of sprouting and the consequent maintenance of quality in potato tubers of Asterix and Challenger cultivars stored during different periods under varying temperatures: eight treatments with and without $1,4-\mathrm{DMN}$ under temperatures of $8{ }^{\circ} \mathrm{C}$ and $20^{\circ} \mathrm{C}$. Treatments effect were evaluated after 0,45 , 90,135 and 180 days after application. The evaluated parameters were the loss of fresh mass, length of the sprouts and activity of the enzymes polyphenoloxidase and peroxidase. The results indicate that the application of 1,4-DMN reduces the loss of fresh mass, this effect was more intense for the cultivar Challenger, at $8^{\circ} \mathrm{C}$. There were also significant effects in reducing the average length of the sprouts for both cultivars evaluated, after 180 days, at $20^{\circ} \mathrm{C}$. There was little or no difference in the level of oxidative stress caused in the tubers. Hence, the effects of 1,4-DMN on the quality control of potatoes included reduced loss of fresh mass and a shorter average length of sprouts for both cultivars evaluated compared to control, for both temperatures. These effects intensify in the cultivar Challenger and treatments with temperatures of $20^{\circ} \mathrm{C}$.
\end{abstract}

Keywords: quality maintenance; sprout suppressor; storage temperature.

Practical Application: This work provides insights into the efficiency of 1,4-Dimethylnaphthalene (1,4-DMN) in suppressing sprout, thus maintaining the quality of potato tubers of Asterix and Challenger cultivars stored under different temperatures during different periods.

\section{Introduction}

Potato is the most relevant tuber in the world (Zhang et al., 2019). Brazilian harvest reached 3.67 million tons in 2021. The Minas Gerais state alone produced 1.21 million tons of potatoes tubers (Instituto Brasileiro de Geografia e Estatística, 2021). Most of these tubers are sold in natura. However, society eating habits are changing towards a stronger demand for processed food. This demand for industrial products creates pressure for uniform, high-quality raw materials in Brazil (Freitas et al., 2006).

Potato tubers destinate for industrial processing must have a high dry matter content, low sugar contents, be free of diseases, damages and physiological disorders (Silva et al., 2019). Sprouting, the breaking dormancy of sprouts, is a major quality problem. Sprouting increases the respiratory rates and causes water loss due to transpiration. Also, it affects the starch content by converting it into reducing sugars, glucose and fructose (Singh \& Kaur, 2016). Besides, sprouts can cause mechanical damage to the adjacent potatoes. These damages favour the contamination by pathogens that depreciates the raw material and causes considerable losses during storage (Mani \& Hannachi, 2015).

Adequate temperature and humidity conditions can reduce the damage coming from these factors. Generally, the optimal storage temperature of potatoes destined for industrial processing is $8^{\circ} \mathrm{C}$ (Voss et al., 2001) since it prolongs dormancy. Along with temperature and humidity control, sprout suppressors are useful in maintaining the quality and extending the durability of stored products.

The chloropropane (CIPC), widely used in the United States and Europa, is among the most efficient sprouting inhibitors. However, the use of CIPC is restricted because of its potential toxic effect on humans and the environment (Paul et al., 2016). In Brazil, the use of CIPC is illegal. Therefore, several studies have investigated alternatives to CIPC which are equally efficient in suppressing sprouting while being safe.

From the characterization of several compounds of the naphthalene family, the 1,4 and 1,6-Dimethylnaphthalene $(1,4-\mathrm{DMN})$ isomers were identified as the most potent sprout suppressors. These suppressors are considered chemicals of low risk for environmental and human health. Hence, they are adequate to suppress sprouting in stored potatoes (Weerd et al., 2010).

These characteristics make 1,4-DMN a candidate product for potato conservation, being useful to study the quality 
maintenance and storage of these tubers. Therefore, the present study aim was to determine the efficiency of 1,4-DMN in suppress sprouting and, consequently, maintain the quality of potato tubers of Asterix and Challenger cultivars stored under different temperatures during different periods (days).

\section{Materials and methods}

\subsection{Experimental design and area characterization}

The experiment was conducted in split-plot design, with the treatments in the plots and the evaluation time in the subplots. A completely randomized design was used, with with four replicates. Each experimental unit was composed of two tubers.

Tubers of the Asterix and Challenger cultivars were planted in March 2017 in Perdizes, 19 $21^{\prime} 10^{\prime \prime} S$ and $47^{\circ} 17^{\prime} 34^{\prime \prime}$ W and climate classified as Cwb according to Köppen and Geiger, characterized by rainy summer and dry winter. Perdizes has an average temperature of $20.1{ }^{\circ} \mathrm{C}$ and the average annual rainfall is $1603 \mathrm{~mm}$. The selection was made regarding mass uniformity, with a variation between 90 and $250 \mathrm{~g}$. The Asterix and Challenger cultivars were chosen because they have quite high yield, numerous tubers and desirable characteristics in the industrial process: tubers with acceptable external appearance, shallow buds, suitable size for obtaining of large toothpicks and oval-elongated shape.

\subsection{Experimental procedure and analyses}

The treatment was applied to the tubers by heating Petri dishes containing filter paper soaked with 1,4-DMN diluted in alcohol until complete volatilization inside the hermetically sealed buckets. The fumigation time was 30 minutes and the treatments were: $\mathrm{T} 1$ - Asterix 1,4-DMN $8{ }^{\circ} \mathrm{C}, \mathrm{T} 2$ - Asterix Control $8^{\circ} \mathrm{C}$, T3 - Asterix 1,4-DMN $20^{\circ} \mathrm{C}, \mathrm{T} 4$ - Asterix Control $20^{\circ} \mathrm{C}$, T5 - Challenger 1,4 -DMN $8{ }^{\circ} \mathrm{C}, \mathrm{T} 6$ - Challenger Control $8^{\circ} \mathrm{C}$, T7 - Challenger 1,4-DMN $20^{\circ} \mathrm{C}, \mathrm{T} 8$ - Challenger Control $20^{\circ} \mathrm{C} .20 \mu \mathrm{L}$ of 1,4-DMN (sigma) per kg of potato were used, diluted in $15 \mathrm{~mL}$ of $95 \%$ alcohol, and the controls contained only $15 \mathrm{~mL}$ of $95 \%$ alcohol (Weerd et al., 2010).

After applying the treatments, the tubers were removed from the buckets and stored in incubators (BOD's), under temperatures of $8{ }^{\circ} \mathrm{C}$ and $20^{\circ} \mathrm{C}$, relative humidity of $85-90 \%$ and absence of light. The temperature of $8^{\circ} \mathrm{C}$ was used because it is suitable for storing potatoes for industrial processing. Already, the temperature of $20^{\circ} \mathrm{C}$ was used because it is the average ambient temperature of the place where the experiment was conducted

Five evaluation periods were performed for each treatment: $0,45,90,135$ and 180 days after application, with day 0 (zero) being evaluated on the day of treatment application. The evaluations were, as follow: loss of fresh mass, length of sprouts, activity of polyphenoloxidase (PPO) and peroxidase (POD) enzymes. All analyzes were performed at the Post-Harvest Technology Technology Laboratory at the Federal University of Viçosa (UFV), in Viçosa-MG.

\subsection{Loss of fresh mass}

The loss of fresh mass was determined by weighing the tubers in each evaluation period, using a semi-analytical balance, taking into account the initial mass, the percentage was obtained by difference during the storage period. The results were expressed as a percentage of fresh mass loss (\%).

\subsection{Sprouts length}

The length of the sprouts was measured in $\mathrm{mm}$, with the aid of a digital caliper (Stainless Hardened). To obtain the sum of the average length of sprouts, the lengths of all the shoots present in each tuber were added and this number was divided by the total number of shoots in the tuber.

\subsection{Polyphenoloxidase (PPO) activity}

Five grams of frozen potatoes from each potato cultivar were immersed in $15 \mathrm{~mL}$ of extraction buffer $(0.1 \mathrm{M}$ potassium phosphate buffer, $\mathrm{pH}$ 6.5). This mixture was ground, filtered through gauze and centrifuged at $12.000 \mathrm{~g}$ for 30 minutes at $4{ }^{\circ} \mathrm{C}$.

The polyphenoloxidase (PPO) activity was determined by adding an enzymatic extract aliquot $(100 \mu \mathrm{L})$ to the reaction medium containing $1.5 \mathrm{~mL}$ of $0.1 \mathrm{M}$ phosphate buffer $(\mathrm{pH} 7.0)$, $0.5 \mathrm{~mL}$ of catechol $(1.68 \%)$ and $3.0 \mathrm{~mL}$ of water. The PPO activity was determined in a spectrophotometer (UV-1601) at $\lambda=420 \eta \mathrm{m}$ at $25^{\circ} \mathrm{C}$. Results were expressed in $\mathrm{EU} / \mathrm{min}^{-1} / \mathrm{mg}^{-1}$ protein (Kavrayan \& Aydemir, 2001). The protein of the enzymatic extract was determined with the method of Bradford (1976) using BSA (bovine serum albumin) as standard. The results were expressed in $\mathrm{mg}$ of protein in the enzyme extract.

\subsection{Peroxidase (POD) activity}

Five grams of frozen potatoes from each potato cultivar were immersed in $15 \mathrm{~mL}$ of extraction buffer $(0.1 \mathrm{M}$ potassium phosphate buffer, $\mathrm{pH}$ 6.5). This mixture was ground, filtered through gauze and centrifuged at $12.000 \mathrm{~g}$ for 30 minutes at $4{ }^{\circ} \mathrm{C}$.

The activity of peroxidase (POD) activity was determined by adding an enzymatic extract aliquot $(200 \mu \mathrm{L})$ to the reaction medium containing $1.5 \mathrm{~mL}$ of $0.1 \mathrm{M}$ phosphate buffer $(\mathrm{pH} 7.0)$, $0.5 \mathrm{~mL}$ of guaiacol (1.68\%), $0.5 \mathrm{~mL}$ of $\mathrm{H}_{2} \mathrm{O}_{2}(1.8 \%)$ and $3 \mathrm{~mL}$ of water. The POD activity was determined in a spectrophotometer (UV-1601) at $\lambda=470 \eta \mathrm{m}$, at $25^{\circ} \mathrm{C}$. Results were expressed in $\mathrm{EU} / \mathrm{min}^{-1} / \mathrm{mg}^{-1}$ protein (Lagrimini et al., 1997). The protein of the enzymatic extract was determined with the method of Bradford (1976) using BSA (bovine serum albumin) as standard. The results were expressed in $\mathrm{mg}$ of protein in the enzyme extract.

\subsection{Data analysis}

The data were submitted to analysis of variance and regression using the SAEG 9.1 Statistical Analysis System (Universidade Federal de Viçosa, 2007) and the means compared by the Tukey test $(\mathrm{p} \leq 0.05)$. The choice of the regression model was based on the significance of the regression coefficients using 
the $t$ test at a 5\% probability level and on the determination coeficiente (R2=SQReg/SQtrat).

\section{Results and discussion}

When assessing the loss of fresh mass over the entire storage period (Table 1), we observed a difference in the fresh mass loss within Asterix cultivar with 1,4-DMN due to the different storage temperatures $\left(8\right.$ and $20^{\circ} \mathrm{C}$ ), with higher losses at $20^{\circ} \mathrm{C}$. That same effect occurred between treatments 2 and 4 after 90, 135 and 180 days of storage of the Asterix cultivar without 1,4-DMN (Table 1). The loss of fresh mass determines, in part, the longevity of storage and also the maintenance of quality (Gupta et al., 2015).

Storage temperature had the same effects on the fresh weight loss in Challenger and 'Asterix' cultivars. Higher losses were observed at $20^{\circ} \mathrm{C}$ at 90,135 and 180 days of storage with $1,4-\mathrm{DMN}$. Similarly, for Challenger with $1,4-\mathrm{DMN}$ at $8^{\circ} \mathrm{C}$ and (treatment 5) and at $20^{\circ} \mathrm{C}$ (treatment 7 ), high losses occurred at 135 and 180 days without the use of 1,4-DMN (Table 1). Therefore, regardless of cultivars and 1,4-DMN application, the loss of fresh mass during storage was associated with higher temperatures.

The effect of storage temperature on the loss of fresh mass is due to increased metabolic activity (Caldiz et al., 1996). Higher respiratory rates lead to intensified mobilization of reserves and water loss via transpiration (Bisognin et al., 2008). Bacarin et al. (2005) found similar results while studying the storage of potato tubers from several cultivars. Asterix cultivar, for example, presented a higher loss of fresh matter when stored under $20^{\circ} \mathrm{C}$.

Interestingly, the Challenger cultivars kept under temperatures of $8{ }^{\circ} \mathrm{C}$ with $1,4-\mathrm{DMN}$ application had a significant reduction in loss of fresh weight (treatment 5 vs 6) at 45 days evaluation. Generally, sprouting correlates positively to mass loss. Thus, the use of sprout suppressors reduces those losses (Azad et al., 2017; Nyankanga et al., 2018). However, the 1,4-DMN effect on sprout inhibition appears to be transient, explaining why there is no significant effect of 1,4-DMN in subsequent evaluation periods. The levels of 1,4-DMN residues within the tubers decrease with increasing storage time (Weerd et al., 2010).
The cultivars under the same storage conditions after 180 days, there was a higher loss of fresh mass in the Asterix cultivar with $1,4-\mathrm{DMN}$ under temperatures of $8{ }^{\circ} \mathrm{C}$. However, for the same temperature without 1,4-DMN the cultivar Challenger showed higher fresh mass loss only at 45 days of evaluation. In the other evaluation periods, the differences were not significant.

Lower losses were observed for the 'Challenger' in the periods of 90,135 and 180 days of storage under $20^{\circ} \mathrm{C}$ with the use of $1,4-\mathrm{DMN}$. Also, considering the same storage temperature of $20{ }^{\circ} \mathrm{C}$ but without the use of $1,4-\mathrm{DMN}$, the 'Challenger' showed fewer losses. This effect was significant in the periods of 135 and 180 days. Nyankanga et al. (2018) observed a significant decrease in mass loss when comparing Kenya Mpya tubers treated with 1,4-DMN and untreated ones.

The linear models adjusted for fresh weight loss shows increased fresh weight loss along time in both cultivars under all treatments (Figure 1). Also, we can observe a greater slope of the line for treatments that considered a higher storage temperature. Proportionally, the temperature factor seems to be a more important contribution to varying fresh weight loss values than the 1,4-DMN factor (Figure 1).

Except for the control treatment at $8^{\circ} \mathrm{C}$ in the Challenger cultivar (1B), determination coefficients $\left(\mathrm{R}^{2}\right)$ above 0.97 were found, indicating that more than $97 \%$ of the variation in fresh weight loss is due to the variation in the storage time considered, according to the adjusted linear models. The loss of tuber mass over the storage period is because of reserve consumption by breathing, the conversion of polysaccharides into sugars and water loss (Finger et al., 2018).

Comparing the effects of storage temperature on the length of sprouts in the Asterix cultivar (Table 2), we found that the use of $1,4-\mathrm{DMN}$ leads to higher sprouts length average values for the storage at $20^{\circ} \mathrm{C}$ in almost all evaluation periods. Exceptionally, at 135 days, there was a greater average length of the sprouts for tubers storage at $8^{\circ} \mathrm{C}$. Although significant, this difference contrasts the pattern observed in the same storage conditions in the other evaluation periods. There is no apparent reason leading to the sprouts damage during this specific evaluation period. Extending dormancy in storage provides potatoes of higher quality for industrial processing

Table 1. Average values for loss of fresh mass (\%) in pottato tubers of Asterix (Ast) and Challenger (Cha) cultivars.

\begin{tabular}{|c|c|c|c|c|c|}
\hline \multicolumn{6}{|c|}{ Loss of Fresh Mass (\%) } \\
\hline Treatment & 0 days & 45 days & 90 days & 135 days & 180 days \\
\hline 1-Ast $/ 1.4-\mathrm{DMN} / 8^{\circ} \mathrm{C}$ & $0.00 \mathrm{~A}$ & $2.02 \mathrm{~B}$ & $3.40 \mathrm{CD}$ & $5.37 \mathrm{C}$ & $6.95 \mathrm{C}$ \\
\hline 2-Ast/Control $/ 8^{\circ} \mathrm{C}$ & $0.00 \mathrm{~A}$ & $2.11 \mathrm{~B}$ & $3.21 \mathrm{CD}$ & $4.38 \mathrm{C}$ & $5.35 \mathrm{CD}$ \\
\hline 3-Ast/1.4-DMN/20 ${ }^{\circ} \mathrm{C}$ & $0.00 \mathrm{~A}$ & $4.48 \mathrm{~A}$ & $7.96 \mathrm{~A}$ & $15.36 \mathrm{~A}$ & $18.35 \mathrm{~A}$ \\
\hline 4-Ast/Control $/ 20^{\circ} \mathrm{C}$ & $0.00 \mathrm{~A}$ & $3.55 \mathrm{AB}$ & $6.40 \mathrm{AB}$ & $13.75 \mathrm{~A}$ & $16.44 \mathrm{~A}$ \\
\hline 5-Cha/1.4-DMN $/ 8^{\circ} \mathrm{C}$ & $0.00 \mathrm{~A}$ & $1.74 \mathrm{~B}$ & $2.76 \mathrm{D}$ & $3.75 \mathrm{C}$ & $4.50 \mathrm{D}$ \\
\hline 6 -Cha/Control $/ 8^{\circ} \mathrm{C}$ & $0.00 \mathrm{~A}$ & $4.57 \mathrm{~A}$ & $4.04 \mathrm{CD}$ & $4.95 \mathrm{C}$ & $5.92 \mathrm{CD}$ \\
\hline 7-Cha/1.4-DMN/20 ${ }^{\circ} \mathrm{C}$ & $0.00 \mathrm{~A}$ & $2.90 \mathrm{AB}$ & $5.43 \mathrm{BC}$ & $8.95 \mathrm{~B}$ & $11.43 \mathrm{~B}$ \\
\hline 8-Cha/Control/20 ${ }^{\circ} \mathrm{C}$ & $0.00 \mathrm{~A}$ & $2.89 \mathrm{AB}$ & $4.89 \mathrm{BCD}$ & $7.75 \mathrm{~B}$ & $11.36 \mathrm{~B}$ \\
\hline
\end{tabular}

Averages followed by the same letter, in the same column, do not differ at $5 \%$ probability by the Tukey test. 


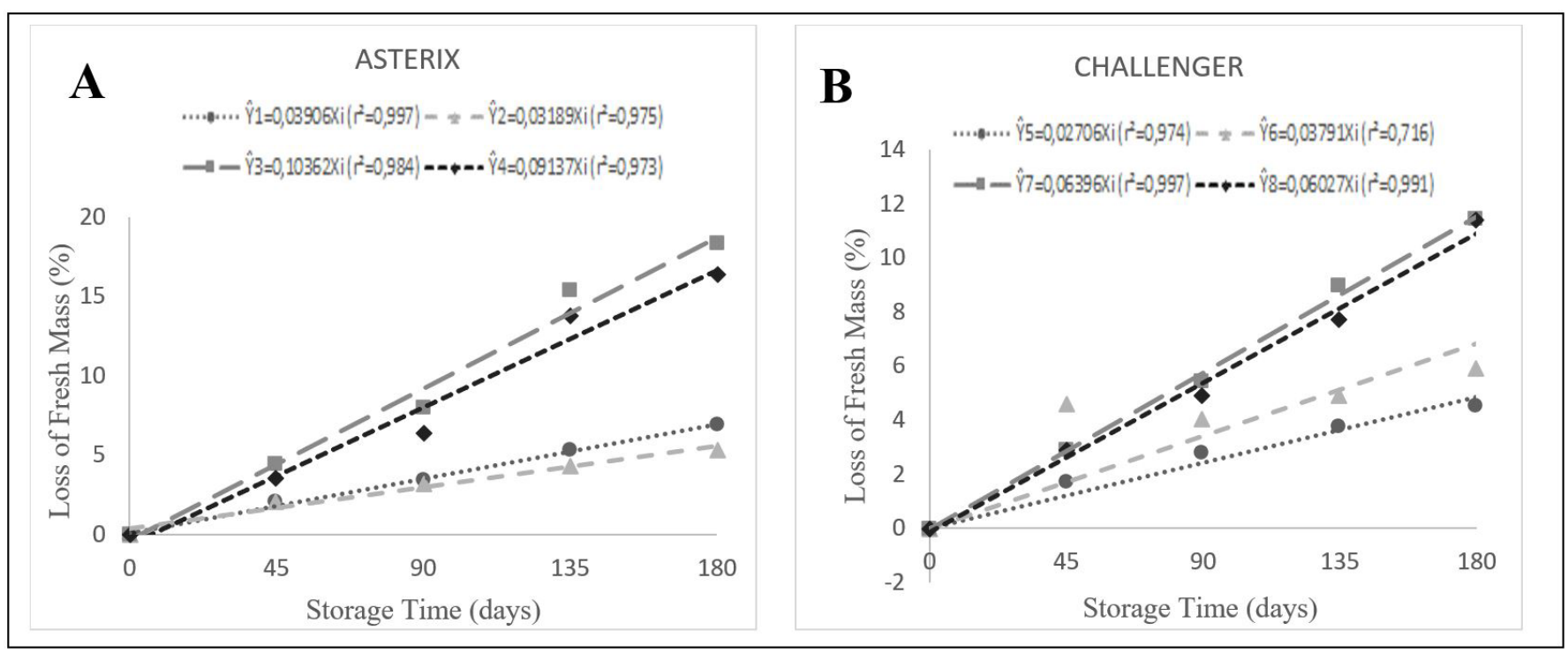

Figure 1. Loss of Fresh Mass (\%) of Asterix (A) and Challenger (B) cultivars, as a function of storage time. $\bullet=1,4-\mathrm{DMN} / 8^{\circ} \mathrm{C}, \boldsymbol{\Delta}=\mathrm{Control} / 8^{\circ} \mathrm{C}$, $\boldsymbol{\square}=1,4-\mathrm{DMN} / 20^{\circ} \mathrm{C}, \boldsymbol{\bullet} \mathrm{Control} / 20^{\circ} \mathrm{C}$.

Table 2. Sum of the average length of sprouts in potato tubers of Asterix (Ast) and Challenger (Cha) cultivars.

\begin{tabular}{|c|c|c|c|c|c|}
\hline \multicolumn{6}{|c|}{ Sum of average sprout length $(\mathrm{mm})$} \\
\hline Treatment & 0 days & 45 days & 90 days & 135 days & 180 days \\
\hline 1-Ast $/ 1.4-\mathrm{DMN} / 8^{\circ} \mathrm{C}$ & $0.00 \mathrm{~A}$ & $0.00 \mathrm{~A}$ & $20.85 \mathrm{AB}$ & $273.52 \mathrm{~A}$ & $83.34 \mathrm{DE}$ \\
\hline 2-Ast/Control $/ 8^{\circ} \mathrm{C}$ & $0.00 \mathrm{~A}$ & $0.00 \mathrm{~A}$ & $18.83 \mathrm{~B}$ & $180.97 \mathrm{~B}$ & $80.00 \mathrm{DE}$ \\
\hline 3-Ast/1.4-DMN/20 ${ }^{\circ} \mathrm{C}$ & $0.00 \mathrm{~A}$ & $6.42 \mathrm{~A}$ & $56.38 \mathrm{AB}$ & $107.68 \mathrm{C}$ & $113.90 \mathrm{D}$ \\
\hline 4-Ast/Control $/ 20^{\circ} \mathrm{C}$ & $0.00 \mathrm{~A}$ & $3.24 \mathrm{~A}$ & $64.04 \mathrm{~A}$ & 87.67 CD & $217.51 \mathrm{~B}$ \\
\hline 5-Cha/1.4-DMN $/ 8^{\circ} \mathrm{C}$ & $0.00 \mathrm{~A}$ & $0.00 \mathrm{~A}$ & $13.11 \mathrm{~B}$ & $66.39 \mathrm{CDE}$ & $61.87 \mathrm{E}$ \\
\hline 6-Cha/Control $/ 8^{\circ} \mathrm{C}$ & $0.00 \mathrm{~A}$ & $0.00 \mathrm{~A}$ & $12.91 \mathrm{~B}$ & $49.78 \mathrm{DE}$ & $78.56 \mathrm{DE}$ \\
\hline 7-Cha/1.4-DMN/20 ${ }^{\circ} \mathrm{C}$ & $0.00 \mathrm{~A}$ & $0.00 \mathrm{~A}$ & $29.85 \mathrm{AB}$ & $44.09 \mathrm{DE}$ & $160.54 \mathrm{C}$ \\
\hline 8-Cha/Control $/ 20^{\circ} \mathrm{C}$ & $0.00 \mathrm{~A}$ & $0.79 \mathrm{~A}$ & $50.51 \mathrm{AB}$ & $39.62 \mathrm{E}$ & $410.24 \mathrm{~A}$ \\
\hline
\end{tabular}

Averages followed by the same letter, in the same column, do not differ at $5 \%$ probability by the Tukey test.

(Freitas et al., 2012). The mode of action of 1,4-DMN is not yet clearly understood, but it has been suggested that the natural dormancy period is extended through the regulation of phytohormones (Campbell et al., 2010).

The Asterix cultivar without 1,4-DMN application showed a greater average length of sprouts under $20^{\circ} \mathrm{C}$ at 90 days of storage and under $8{ }^{\circ} \mathrm{C}$ in the period of 135 days. After 135 days, the length of the sprouts was equal (Table 2). For the Challenger cultivar, with and without 1,4-DMN, the higher storage temperature resulted in a significant higher length of sprouts, but only in the period of 180 days. The effects of 1,4-DMN in reducing the average length of the sprouts were significant for both cultivars, but only after a longer storage period (180 days) under $20^{\circ} \mathrm{C}$.

Nyankanga et al. (2018), when testing the use of 1,4-DMN in different potato cultivars, found that the use of DMN did not prevent the beginning of sprouting in the Shangi and Asante cultivars, but significantly reduced the development of sprouting during storage compared to untreated tubers. They also observed that the use of 1,4-DMN effectively suppressed the growth of sprouts compared to untreated tubers.
The best models adjusted for average sprouts length were linear and increasing (Figure 2). Thus, an increasing linear relationship between storage time and this characteristic is expected. The equations adjusted for the control treatments at $20{ }^{\circ} \mathrm{C}$ showed a greater inclination in both cultivars for sprouts length (Figure 2). That was mainly due to the higher averages observed for these characteristics after a long period of storage. Different cultivars require different levels of suppressors in the tubers to suppress sprouting during storage (Nyankanga et al., 2018).

For the Challenger cultivar, there was no effect of the storage temperature on the average levels of polyphenoloxidase (PPO), both in the presence and in the absence of 1,4-DMN (Table 3). Whereas, the Asterix cultivar with 1,4-DMN presented a higher average of PPO under $20^{\circ} \mathrm{C}$ at 45 days and a lower average without $1,4-\mathrm{DMN}$ under $20^{\circ} \mathrm{C}$ at 35 days. There was no effect of $1,4-\mathrm{DMN}$ on the average of PPO in any storage condition for both cultivars evaluated.

Comparison between cultivars under the same storage conditions showed a significant difference only in the presence of 1,4-DMN at 45 days (Table 3), with a higher mean of 
polyphenoloxidase for the Asterix cultivar. The increase in PPO activity may be related to the tuber defence mechanisms generated by physiological changes at the beginning of sprouting (Afify et al., 2012).

Peroxidase activity (POD) is associated with enzymatic browning through oxidation of phenolic compounds, which causes deterioration and loss in product quality due to changes in colour and flavour (Terefe et al., 2014). It is possible to observe a trend of lower POD activity for tubers stored under $20^{\circ} \mathrm{C}$. However, there was no significant effect of any of the factors studied (cultivar, temperature, 1,4-DMN and storage time) on POD levels when comparing Challenger and Asterix cultivars under the same storage condition (Table 4).

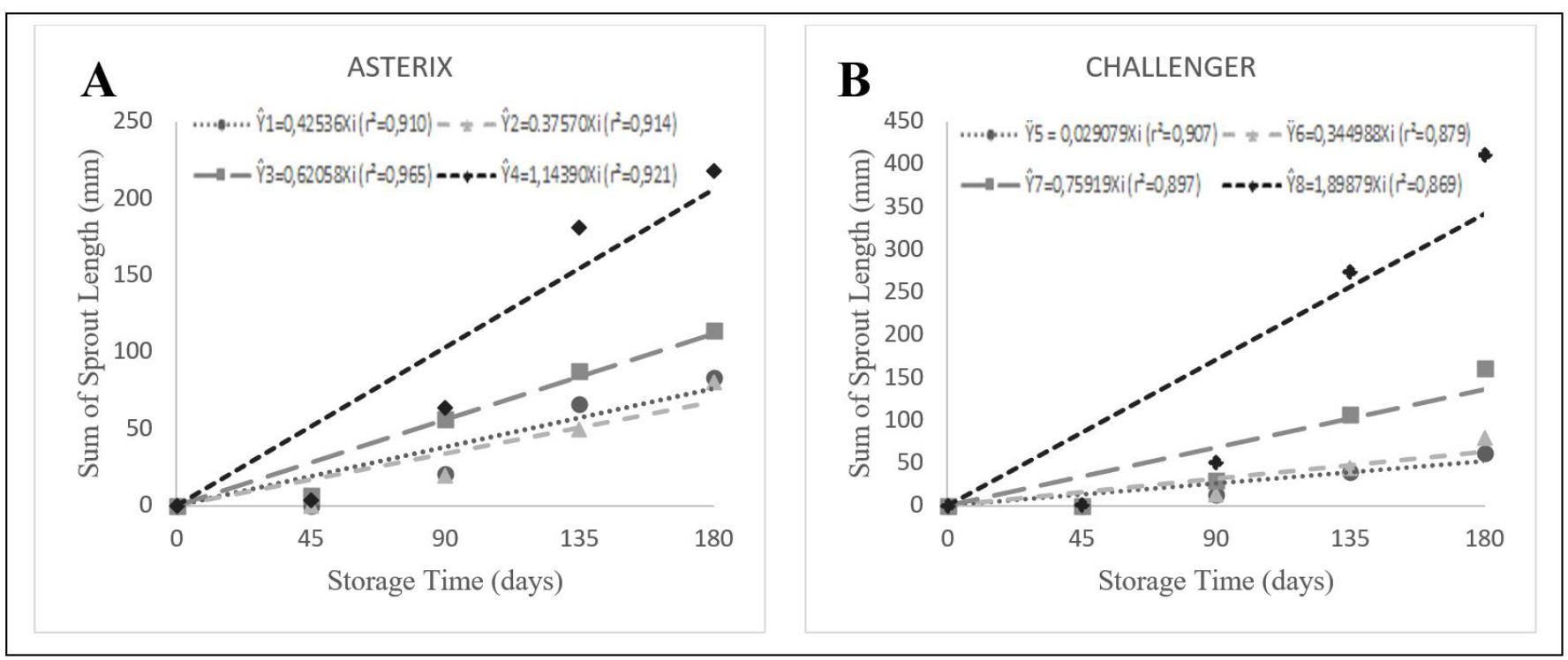

Figure 2. Sum of the average length of the sprouts of Asterix (A) and Challenger (B) cultivars, as a function of storage time. $-1,4-\mathrm{DMN} / 8^{\circ} \mathrm{C}$, $\boldsymbol{\Delta}=$ Control $/ 8^{\circ} \mathrm{C},=1,4-\mathrm{DMN} / 20^{\circ} \mathrm{C}, \boldsymbol{C}=\mathrm{Control} / 20^{\circ} \mathrm{C}$.

Table 3. Average values for polyphenoloxidase enzyme activity in potato tubers of Asterix (Ast) and Challenger (Cha) cultivars.

\begin{tabular}{|c|c|c|c|c|c|}
\hline \multicolumn{6}{|c|}{ Polyphenoloxidase enzyme (UA/min/mg of protein) } \\
\hline Treatment & 0 days & 45 days & 90 days & 135 days & 180 days \\
\hline 1 -Ast $/ 1.4-\mathrm{DMN} / 8^{\circ} \mathrm{C}$ & $0.600 \mathrm{~A}$ & $0.235 \mathrm{~B}$ & $1.055 \mathrm{~A}$ & $1.156 \mathrm{AB}$ & $0.339 \mathrm{~A}$ \\
\hline 2-Ast/Control/ $8{ }^{\circ} \mathrm{C}$ & $0.369 \mathrm{~A}$ & $0.177 \mathrm{~B}$ & $1.055 \mathrm{~A}$ & $1.847 \mathrm{~A}$ & $1.102 \mathrm{~A}$ \\
\hline 3-Ast/1.4-DMN/20 ${ }^{\circ} \mathrm{C}$ & $0.592 \mathrm{~A}$ & $1.878 \mathrm{~A}$ & $1.844 \mathrm{~A}$ & $0.170 \mathrm{~B}$ & $0.257 \mathrm{~A}$ \\
\hline 4-Ast/Control $/ 20^{\circ} \mathrm{C}$ & $0.364 \mathrm{~A}$ & $1.496 \mathrm{AB}$ & $0.939 \mathrm{~A}$ & $0.255 \mathrm{~B}$ & $0.402 \mathrm{~A}$ \\
\hline 5-Cha/1.4-DMN/8 ${ }^{\circ} \mathrm{C}$ & $0.323 \mathrm{~A}$ & $0.859 \mathrm{AB}$ & $1.673 \mathrm{~A}$ & $0.249 \mathrm{~B}$ & $0.258 \mathrm{~A}$ \\
\hline 6-Cha/Control $/ 8^{\circ} \mathrm{C}$ & $0.238 \mathrm{~A}$ & $0.273 \mathrm{~B}$ & $1.542 \mathrm{~A}$ & $0.569 \mathrm{AB}$ & $0.333 \mathrm{~A}$ \\
\hline 7-Cha/1.4-DMN $/ 20^{\circ} \mathrm{C}$ & $0.322 \mathrm{~A}$ & $0.282 \mathrm{~B}$ & $1.222 \mathrm{~A}$ & $0.660 \mathrm{AB}$ & $0.181 \mathrm{~A}$ \\
\hline 8-Cha/Control $/ 20^{\circ} \mathrm{C}$ & $0.238 \mathrm{~A}$ & $0.482 \mathrm{AB}$ & $1.289 \mathrm{~A}$ & 0.145 B & $0.319 \mathrm{~A}$ \\
\hline
\end{tabular}

Averages followed by the same letter, in the same column, do not differ at $5 \%$ probability by the Tukey test.

Table 4. Average values for peroxidase enzyme activity in potato tubers of Asterix (Ast) and Challenger (Cha) cultivars.

\begin{tabular}{|c|c|c|c|c|c|}
\hline \multicolumn{6}{|c|}{ Peroxidase enzyme (UA/min/mg of protein) } \\
\hline Treatment & 0 days & 45 days & 90 days & 135 days & 180 days \\
\hline 1-Ast $/ 1.4-\mathrm{DMN} / 8^{\circ} \mathrm{C}$ & $1.036 \mathrm{~A}$ & $0.128 \mathrm{~A}$ & $0.708 \mathrm{~A}$ & $0.370 \mathrm{~A}$ & $0.352 \mathrm{~A}$ \\
\hline 2-Ast/Control $/ 8^{\circ} \mathrm{C}$ & $0.489 \mathrm{~A}$ & $0.175 \mathrm{~A}$ & $0.540 \mathrm{~A}$ & $0.592 \mathrm{~A}$ & $0.790 \mathrm{~A}$ \\
\hline 3-Ast/1.4-DMN/20 ${ }^{\circ} \mathrm{C}$ & $1.027 \mathrm{~A}$ & $0.161 \mathrm{~A}$ & $0.468 \mathrm{~A}$ & $0.082 \mathrm{~A}$ & $0.031 \mathrm{~A}$ \\
\hline 4-Ast/Control $/ 20^{\circ} \mathrm{C}$ & $0.493 \mathrm{~A}$ & $0.167 \mathrm{~A}$ & $0.427 \mathrm{~A}$ & $0.111 \mathrm{~A}$ & $0.042 \mathrm{~A}$ \\
\hline 5-Cha/1.4-DMN $/ 8^{\circ} \mathrm{C}$ & $0.160 \mathrm{~A}$ & $0.000 \mathrm{~A}$ & $0.299 \mathrm{~A}$ & $0.172 \mathrm{~A}$ & $0.018 \mathrm{~A}$ \\
\hline 6-Cha/Control $/ 8^{\circ} \mathrm{C}$ & $0.093 \mathrm{~A}$ & $0.148 \mathrm{~A}$ & $0.298 \mathrm{~A}$ & $0.166 \mathrm{~A}$ & $0.303 \mathrm{~A}$ \\
\hline 7-Cha/1.4-DMN/20 ${ }^{\circ} \mathrm{C}$ & $0.156 \mathrm{~A}$ & $0.253 \mathrm{~A}$ & $0.204 \mathrm{~A}$ & $0.374 \mathrm{~A}$ & $0.012 \mathrm{~A}$ \\
\hline 8-Cha/Control $/ 20^{\circ} \mathrm{C}$ & $0.092 \mathrm{~A}$ & $0.125 \mathrm{~A}$ & $0.187 \mathrm{~A}$ & $0.061 \mathrm{~A}$ & $0.049 \mathrm{~A}$ \\
\hline
\end{tabular}

Averages followed by the same letter, in the same column, do not differ at $5 \%$ probability by the Tukey test. 
Polyphenoloxidase and peroxidase are enzymes related to the oxidative stress of the plant. Higher stress levels lead to higher production of these enzymes. These enzymes reduce the levels of reactive oxygen species (ROS) (Brito et al., 2005), which could compromise several cellular structures, such as the plasma membrane, cell organelles, nucleic acids, lipids and proteins. These results indicate that there is little or no difference regarding the level of oxidative stress in both cultivars studied here.

\section{Conclusion}

The effects of 1,4-DMN in the quality control of potatoes resulted in less loss of fresh mass and reduction in the average length of the sprouts for the cultivars Asterix and Challenger. These effects were more effective for the cultivar Challenger and at a temperature of $20^{\circ} \mathrm{C}$.

\section{Acknowledgements}

The authors thank FAPEMIG (Minas Gerais State Research Support Foundation), CNPq (National Council for Scientific and Technological Development) and CAPES (Coordination for the Improvement of Higher Education Personnel).

\section{References}

Afify, A. E. M. M., El-Beltagi, H. S., Aly, A. A., \& El-Ansary, A. E. (2012). Antioxidant enzyme activities and lipid peroxidation as biomarker for potato tuber stored by two essential oils from Caraway and Clove and its main component carvone and eugenol. Asian Pacific Journal of Tropical Biomedicine, 2(2), S772-S780. http://dx.doi.org/10.1016/ S2221-1691(12)60312-8.

Azad, A. K., Kabir, H., Eaton, T. E. J., \& Soren, E. B. (2017). Storage potentialities of some exotic potato varieties at farmers' condition in Bangladesh. Agricultural Sciences, 8(2), 183-193. http://dx.doi. org/10.4236/as.2017.82013.

Bacarin, M. A., Ferreira, L. S., Deuner, S., Bervald, C. M. P., Zanatta, E. R., \& Lopes, N. F. (2005). Carboidratos não estruturais em tubérculos de batata recondicionados após o armazenamento sob diferentes temperaturas. Horticultura Brasileira, 23(3), 799-804. http://dx.doi. org/10.1590/S0102-05362005000300022.

Bisognin, D. A., Freitas, A. T., Brackmann, A., Andriolo, J. L., Pereira, E. I. P., Muller, D. R., \& Bandinelli, M. G. (2008). Envelhecimento fisiológico de tubérculos de batata produzidos durante o outono e a primavera e armazenados em diferentes temperaturas. Bragantia, 67(1), 59-65. http://dx.doi.org/10.1590/S0006-87052008000100007.

Bradford, M. M. A. (1976). Rapid and sensitive method for the quantification of microgram quantities of protein utilizing the principle of protein-dye biding. Analytical Biochemistry, 72(1-2), 248-254. http://dx.doi.org/10.1016/0003-2697(76)90527-3. PMid:942051.

Brito, C. A. K. D., Sato, H. H., Spironello, A., \& Siqueira, W. J. (2005). Características da atividade da peroxidase de abacaxis (Ananas comosus (L.) Merrill) da cultivar IAC Gomo-de-mel e do clone IAC-1. Food Science and Technology, 25(2), 244-249. http://dx.doi. org/10.1590/S0101-20612005000200010.

Caldiz, D. O., Brocchi, G., Alaniz, J., \& Marchan, C. (1996). Effects of the physiological age of seed potatoes on tuber initiation and starch and dry matter accumulation. Pesquisa Agropecuária Brasileira, 31(12), 853-858.

Campbell, M. A., Gleichsner, A., Alsbury, R., Horvath, D., \& Suttle, J. (2010). The sprout inhibitors chlorpropham and 1, 4-dimethylnaphthalene elicit different transcriptional profiles and do not suppress growth through a prolongation of the dormant state. Plant Molecular Biology, 73(1-2), 181-189. http://dx.doi.org/10.1007/s11103-010-9607-6. PMid:20135197.

Finger, F. L., Santos, M. M. D. S., Araujo, F. F., Lima, P. C. C., Costa, L. C. D., França, C. D. F. M., \& Queiroz, M. D. C. (2018). Action of essential oils on sprouting of non-dormant potato tubers. Brazilian Archives of Biology and Technology, 61(1), e18180003. http://dx.doi. org/10.1590/1678-4324-2018180003.

Freitas, S. T. D., Bisognin, D. A., Gómez, A. C. S., Sautter, C. K., Costa, L. C. D., \& Rampelotto, M. V. (2006). Qualidade para processamento de clones de batata cultivados durante a primavera e outono no Rio Grande do Sul. Ciência Rural, 36(1), 80-85. http://dx.doi.org/10.1590/ S0103-84782006000100012.

Freitas, S. T., Pereira, E. I. P., Gomez, A. C. S., Brackmann, A., Nicoloso, F., \& Bisognin, D. A. (2012). Processing quality of potato tubers produced during autumn and spring and stored at different temperatures. Horticultura Brasileira, 30(1), 91-98. http://dx.doi. org/10.1590/S0102-05362012000100016.

Gupta, V. K., Luthra, S. K., \& Singh, B. P. (2015). Storage behaviour and cooking quality of Indian potato varieties. Journal of Food Science and Technology, 52(8), 4863-4873. http://dx.doi.org/10.1007/s13197014-1608-z. PMid:26243906.

Instituto Brasileiro de Geografia e Estatística - IBGE. (2021). Levantamento sistemático da produção agrícola. Retrieved from https://sidra.ibge. gov.br/Tabela/1618\#resultado

Kavrayan, D., \& Aydemir, T. (2001). Partial purification and characterization of polyphenoloxidase from peppermint (Mentha piperita). Food Chemistry, 74(2), 147-154. http://dx.doi.org/10.1016/ S0308-8146(01)00106-6.

Lagrimini, L. M., Gingas, V., Finger, F., Rothstein, S., \& Liu, T. T. Y. (1997). Characterization of antisense transformed plants deficient in the Tobacco Anionic peroxidase. Plant Physiology, 114(4), 11871196. http://dx.doi.org/10.1104/pp.114.4.1187. PMid:12223765.

Mani, F., \& Hannachi, C. (2015). Physiology of potato sprouting. Journal of Nature and Science, 17(2), 591-602.

Nyankanga, R. O., Murigi, W. W., Shibairo, S. I., Olanya, O. M., \& Larkin, R. P. (2018). Effects of foliar and tuber sprout suppressants on storage of ware potatoes under tropical conditions. American Journal of Potato Research, 95(5), 539-548. http://dx.doi.org/10.1007/s12230018-9662-0.

Paul, V., Ezekiel, R., \& Pandey, R. (2016). Sprout suppression on potato: need to look beyond CIPC for more effective and safer alternatives. Journal of Food Science and Technology, 53(1), 1-18. http://dx.doi. org/10.1007/s13197-015-1980-3. PMid:26787928.

Silva, G. O. D., Pereira, A. D. S., Carvalho, A. D., \& Azevedo, F. Q. (2019). Yield, frying quality, plant vigor, and maturity of potato clones. Horticultura Brasileira, 37(1), 95-100. http://dx.doi.org/10.1590/ s0102-053620190115.

Singh, J., \& Kaur, L. (2016). Advances in potato chemistry and technology (2nd ed.). London: Academic Press.

Terefe, N. S., Buckow, R., \& Versteeg, C. (2014). Quality-related enzymes in fruit and vegetable products: effects of novel food processing technologies, part 1: high-pressure processing. Critical Reviews in Food Science and Nutrition, 54(1), 24-63. http://dx.doi.org/10.108 0/10408398.2011.566946. PMid:24188232.

Universidade Federal de Viçosa - UFV. (2007). SAEG - Sistema para análises estatísticas, versão 9.1. Viçosa. Retrieved from http:// arquivo.ufv.br/saeg/

Voss, R. E., Baghott, K. G., \& Timm, H. (2001). Proper environment for potato storage. Vegetable Research and Information Center, 1(1), 1-3. 
Weerd, J. W., Thornton, M. K., \& Shafii, B. (2010). Sprout suppressing residue levels of 1,4-dimethylnaphthalene $(1,4-\mathrm{DMN})$ in potato cultivars. American Journal of Potato Research, 87(5), 434-445. http://dx.doi.org/10.1007/s12230-010-9146-3.
Zhang, H., Yao, Y., Chen, S., Hou, J., Yu, Y., Liu, T., Du, J., Song, B., \& Xie, C. (2019). SbRFP1 regulates cold-induced sweetening of potato tubers by inactivation of StBAM1. Plant Physiology and Biochemistry, 136(1), 215-221.http://dx.doi.org/10.1016/j.plaphy.2019.01.019. PMid:30690278. 